\title{
世界的な飢餓に立ち向かうために
}

\section{How to feed a hungry world}

2010 年 7 月 29 日号 Vol. 466 (531-532)

2050 年の地球の推定総人口 91 億人に、十分な食料を供給するのは可能だとされる。

しかし、それを許容できるコストで実現できるかどうかは、

ハイテク育種だけでなく農法のようなローテクに至るまで、多種多様な農業研究がカギを握っている。

現在 68 億人の世界の総人口は、2050 年には 91 億人に増加すると予想されて おり、「人口増加を食い止めなければ、 食料の供給が追いつかなくなる」という マルサス学説に基づいた懸念が生まれて いる。1961 年には 30 億人だった世界 人口は、2007 年にはその 2 倍以上になっ た。ところが、農業生産高はそれに見 合った伸びを示し、現在の予測（Nature 2010 年 7 月 29 日号 546 ページ、本誌 8 ページ参照) では、このペースが維持 される見通しになっている。

ただし、これには、世界の耕地面積が 拡大し、今以上に大量の肥料と農薬を散 布して、既に相当に減っている地下水源 をさらに利用すれば、という条件がつい ている。したがって、資源消費と環境破 壊による現代農法をさらに普及させつ つ、中南米とアフリカを中心とした数億 ヘクタールの荒れ地を開墾することは、 賢明な選択肢とはいいがたい。ここに、 今後数十年間にわたる現実の課題があ る。すなわち、土地の利用面積をさほど 増やさずに農業生産高を急増させる方法 を構築しなければならないのだ。

第二の緑の革命が必要とされている。 英国学士院は、この第二の緑の革命を 「世界農業の持続可能な集約化」と巧妙 に説明している。この革命では、優先順 位を大幅に見直す必要がある。収量増を もたらす一方で、水、肥料やそのほかの 資材の消費を減らす新たな作物品種が 緊急に求められているのだ。こうした品 種は、例えば、長い間軽視されていた根
の改良研究によって作出される（同号 552 ページ、本誌 10 ページ参照)。ま た、干ばつ、高温、冠水や病害虫に対す る抵抗性を高めた作物の開発も急務と なっている。同時に極めて重要なのが、 輪作、小規模農家による農作物と家畜の 混合農業、土袞管理、廃棄物削減といっ たハイテク度の低い研究だ。現実に、全 世界の作物の 4 分の 1 から 3 分の 1 が 栽培中に失われているからだ。

開発途上国では、現代の技術や農法を もつと上手に活用することで、生産性を 大きく伸ばすことは可能だ。しかし、そ のためには資金が必要だ。FAO の試算 によれば、2050 年の食料需要を満たす には、開発途上国の農業全体への投資額 を年間 830 億ドル（約 7 兆円）に倍増 する必要があるとされる。この投資のほ とんどは、生産から貯蔵、加工に至る農 業インフラの改良に向けられる必要があ る。アフリカでは、農業生産性の向上が、 道路不足によっても妨げられている。道 路整備の遅れで、農家は化学肥料の入手 に苦労し、高額の出費を余儀なくされて いる。また、研究課題を定めるに当たつ ては、世界人口の過半数が生活し、今後 数十年間の人口増加が最も顕著となる最 貧国抢よび最も資源の乏しい国々のニー ズを重視することが必要だ。とりわけ、 農業の再構築には、生物学者、農学者、 農家だけでなく、生態学者、政策立案者、 社会科学者も関与する多領域的アプロー チが必要だ。

一方で、遺伝子組み換え作物は、従来
の育種技術と並んで、持続可能な農業の ための重要な道具の 1 つだ。しかしそ れは、世界の飢餓に対する根本的な解決 策ではない。実際、第一世代の遺伝子組 み換え作物は、貧困国とはほとんど関係 がない。組み換え作物の利点を誇張する ことは、一般市民の不信を高めるだけだ。 農業の私営化や独占化の動き、あるいは 利益重視の姿勢に対する懸念をも増幅さ せるからだ。

科学も技術もそれ自体では、世界的な 飢餓に対する解決策にはならない。飢餓 の根本原因は、食料生産高の不足ではな く、貧困にあるからだ。現在、地球上で は、需要を十二分に満たすだけの食料が 生産されているのに、それでも約 10 億 人が飢餓状態にある。それは食料を買う 金がないからなのだ。約 1 億人が飢餓 状態に陥つた 2008 年の食料危機の実態 は、食料不足ではなく、食料価格の高騰 であった。このほかにも、経済が、食料 の供給にいろいろな悪影響を及ぼしてい る。経済協力開発機構（OECD）の加盟 各国は、国内の農家に膨大な補助金を支 給しており、その総額は、1 日当たり約 10 億ドル（約 850 億円）に達している。 そのため、開発途上国の農業が世界市場 に足がかりを得ることを非常に難しくし ている。

それでもなお、研究によって持続可能 で生産性の高い農業を実現することが、 人々を貧困から救い出す 1 つの処方箋で あることに間違いはないのだ。

(翻訳 : 菊川要、要約 : 編集部) 